\title{
Sustainability Reporting and Discretionary Accruals of Multinational Corporations in Sub-Saharan Africa
}

\author{
Ishola Rufus AKINTOYE \\ Professor of Accounting \& Strategic Financial Management, \\ Department of Accounting, School of Management Sciences, \\ Babcock University Ilishan-Remo, Nigeria \\ Folajimi Festus ADEGBIE \\ Professor of Accounting \\ Department of Accounting, School of Management Sciences, \\ Babcock University Ilishan-Remo, Nigeria \\ Ibukun FALAYI \\ Department of Accounting, School of Management Sciences, \\ Babcock University Ilishan-Remo, Nigeria
}

\begin{abstract}
The quality of accounting information has attracted considerable interests among many scholars, investors, and other stakeholders worldwide. Earnings management is one of the factors responsible for this development. However, studies have shown that sustainability reporting can assist companies in reducing information asymmetry which encourages earnings' manipulation. Hence, the paper investigated how sustainability reporting could influence accrualsbased earnings management among multinational corporations in Sub-Saharan Africa countries. The research' design wasex-post facto. All the 48 multinational companies in thesub-Saharan Africa countries constituted the study's population. Purposive sampling technique was used in selecting 5 multinational companies from each of 10 sampled countries based on data availability. The data for the period 2010-2019 were obtained from the published annual financial reports of the sampled multinational companies and the Global Reporting Initiatives (GRI)'s sustainability guidelines. The study revealed that the lag of discretionary accruals, corporate governance sustainability reporting and economic sustainability reporting had positive relationship with discretionary accruals, while social sustainability reporting and environmental sustainability reporting were negatively linked to discretionary accruals. Additionally, the study found that sustainability reporting jointly had significant effect on discretionary accruals of multinational corporations in Sub-Saharan Africa (Adj. $\mathrm{R}^{2}=0.33$, $W(6,444)=668.67, P<.05)$. This study concluded that sustainability reporting exerted significant influence on discretionary accruals of multinational corporations in Sub-Sahara Africa. The study recommended that management of multinational corporations in sub-Saharan Africa should ensure strict compliance with sustainability reporting so as to improve the earnings quality.
\end{abstract}

Keywords: Sustainability reporting, environmental reporting, economic reporting, social reporting, corporate governance reporting, earnings management, discretionary accruals.

DOI: $10.7176 /$ RJFA/12-24-02

Publication date: December $31^{\text {st }} 2021$

\section{Introduction}

The quality of accounting information has been brought to the fore by many scholars, investors, and other stakeholders worldwide. This phenomenon is not unconnected with the recent accounting scandals caused the bankruptcy of many large organizations like Enron, Parmalat and Maxwel across the world (Hussain, Akbar, Khan, Akbar, Panait, \& Voica, 2020). Earnings management is reputed for having the capacity to distort actual accounting information presented to multiple users (Hussain, et al., 2020; Mason, \& Morton, 2020). The distortions occasioned by these manipulations of earnings reporting portend grave consequences to stakeholders in terms of confidence in accounting reporting, corporate image, and borrowing capacity. Investors and financial analysts who rely on such manipulated accounting information for measuring the present value of future earnings are misled (Oraby, 2017). Earnings management exerts negative impact on corporate reputation and reduces the entity's capacity to access loans and debts (Setiawan \& Hermawan, 2018).

Managers, due to their vantage position, possess more facts and figures about the activities of the business than otherstakeholders and are inclined to evaluate how alternative methods would affect their wealth (Watts \& Zimmerman, 1986; Demsetz \& Lehn, 1985). Consequently, information asymmetry is created between the managers who hold privileged or private information and other stakeholders who would have taken informed decisions if they were aware of it (Connelly, Certo, Ireland, \&Reutzel, 2011). Thus, the same kind of information is not equitably distributed in the market or available to the market participants in the same form. 
Sustainability reporting can assist companies in reducing information asymmetry thereby lowering agency costs and enhancing the protection of stakeholders' interests (Hu \&Loh, 2018).Besides, it also promotes conformity to social norms by disclosing social and environmental information and thereby enhancing legitimacy and acceptance by the people (De Villiers \&Maques, 2016). Other inherent benefits of sustainability are employee participation in the firm's activities and enhancement of the image and status of the firm (Orlitzky \& Swanson, 2012; Becchetti, Di Giacomo, \& Pinnacchio, 2008).

Studies have been carried out on sustainability reporting and accruals based earnings management in the Indonesia, France, Germany, Korea and other locations (Trisnawati, Wiyadi \& Setiawati, 2016; Amar \& Chakroun, 2018; Amar \& Chakroun, 2018; Velte, 2019; Ji, Oh, Yoon \& An, 2019). However, there is paucity of empirical evidence on the relationship between sustainability reporting and accrual based earnings management that is specific to Sub Saharan Africa.

The fulcrum of this study is that sound corporate governance, environmental, economic, environmental, and social sustainability reporting practices can lead to less discretionary accruals in earnings quality of multinational corporations in Sub-Saharan Africa.

\section{Literature Review and Theoretical Review}

This section covers the conceptual review, theoretical review and the empirical review on sustainability reporting and earnings management. The stakeholders' theory, signaling theory and legitimacy theory are considered theoretically relevant to this study. They are reviewed below.

\subsection{Conceptual Review}

\subsubsection{Discretionary Accruals}

Discretionary accruals refer to the portion of total accruals that can be manipulated easily by managers hiding behind accounting rules and principles. That portion of total accruals is not incurred in the ordinary course of business activity and is not directly discernible but has impact on the quality of earnings. In Literature, many researchers have given considerable attention to the study of accruals because they hold the belief that accruals is a key tool of earnings' manipulation, hence their interests in estimating accruals precisely (Acar \& Yilmaz, 2020).

Schipper (1989) provided a definition for earnings management. He described it as the intentional activities of a manager which would produce financial statements that the manager would make some underserved gain. Specifically, accrual-based earnings management refers to manage earnings of a firm by changing an accounting policy or adjusting an estimate while real earnings management involves operational activities to manage earnings of a firm by reducing its sales or cutting its expenses (Yun, Ryu, \& Ji, 2019).

Roychowdhury (2006) stated that stakeholders cannot distinguish earnings adjusted by real earnings management from real earnings, and suggested a real earnings management-related empirical model with which a firm's normal business activities can be differentiated from abnormal ones. Cohen et al. (2008) suggested that real earnings management (having the relatively lower legal expense and responsibility than accrual-based earnings management) has become more widely used after the enforcementof the SOX act. Cohen and Zarowin (2010) reported that managers were more likely to use real earnings management upon recapitalization. Ji (2018) reported that real earnings managementwas more likely to occur in the firms hosting briefing sessions, expecting an investment of the market, than others, to secure the market's trust. Yun et al. (2019) reported that real earnings management occurred in firms in which the influence of a CEO was huge; such tendency could be controlled to a certain extent with the audit. Ji and An (2019) reported that firms seeking for mutual development tend to be less involved in real earnings management than others.

\subsubsection{Sustainability Reporting}

Sustainability reporting is an important system of communicating ethical compliance by the organization in order to reduce pressure from stakeholders (Hahn \& Kuhnen, 2013). Schaltegger, Etxeberria and Ortas (2017), criticized the current traditional accounting system because it is not adequate enough to report the genuine picture of an organization impacts and the effort at ensuring sustainability improvements. Sustainability reporting assists companies in reducing information asymmetry which dissuades earnings' manipulation.Sustainability reporting can be viewed from three perspectives: environmental sustainability, governance sustainability and social sustainability (Akintoye, Taiwo, \& Owolabi, 2020).

Wealth maximization is the predominant focus of the firm but as rationalized by shareholders and legitimacy theories, this goal should not be achieved without economic, social, governance and environmental considerations in the decision making process.

Due to the fact that strategic management decision involves the allocation of scarce corporate resources by managers in a dynamic environment, reporting on sustainability will assist organizations in achieving long term business performance objectives (Waddock \& Graves 1997). 


\subsection{Theoretical Review}

\subsubsection{Stakeholders' Theory}

The dominant focus of businesses is to maximize value. The issue has always been who should be the beneficiary of the value created or who the businesses should be responsible to. Should it be for the providers of capital (shareholders) alone or to them as well as other stakeholders: government, society, and employees? Friedman (1970) offered a rational explanation in his Shareholder Theory. He averred that businesses should be responsible to the shareholders whom he regarded as the economic engine of the organization. He asserted that the goal of the firm should be maximization of returns (value) to the shareholders. According to him, it is the not the place of managers (as employees and agents) to decide which social initiatives the shareholders should be involved in.

Stakeholder theory championed by Freeman (1984) is diametrically opposed to Friedman's (1970) doctrine of shareholders' primacy. The use of the word "stakeholder" as part of academic lexicon owes its origin to a memo at the Stanford Research Institute (Stewart, Allen \& Cavender, 1963).

The memo identifies shareholders as shareholders, employees, customers, suppliers, lenders and society, and opines that organization would cease to exist without their support. Managers (executives), on account of this, need to internalize the needs and concerns of the stakeholders in the formulation of corporate objectives to secure the long term goals of the economic entity.

Freeman (1984) further championed the stakeholder theory. He sees a stakeholder as "any group or individual who can affect or is affected by the achievement of the organization's objectives". The theory sets out to resolve three problems: value creation and trade, ethics of capitalism and managerial mindset (Freeman, 1984). Kroos and Schwab (1971) reckoned that long-term growth and prosperity of an enterprise rest on the ability to satisfy the highly divergent needs and wishes of its stakeholders. Quality earnings information and evidence of the firm's environmental commitment to sustainable economic development are part of these needs and wishes.

\subsubsection{Signaling Theory}

Signalling theory shows how communication is achieved among actors amidst information asymmetry (Spence, 1973). The theory affirms that they are two actors: the signal sender and the signal receiver. The sender elects whether and how to send the signal while the receiver is left with the choice of how to interpret the signal (Etengu, Olweny \& Oluoch, 2019). It throws light on the process through which the firm conveys its quality and potential information, and the outside actors access the underlying, often unobservable, attributes of the entity (Drover, Wood \& Corbett, 2018). The theory postulates that the essence of the signals is to reduce information gaps or asymmetries between the two parties (Drover, Wood \& Corbett, 2018; Saleh, Afifa \& Haniah, 2020). Spence (1973) sees signals as activities of people in a market which, planned or unplanned, alter the views or opinions of, or send information to, other people in the market.

Market efficiency postulates that the investors are rational at given time and that the value of an entity's stock mirrors and incorporates all the available information. Investors will ordinarily offer lower price for an entity's share on the premise that managers have more facts on the company and its future prospects. Conversely, Connelly, Certo, Ireland and Reutzel (2011) posit that the company's value is enhanced where the company voluntarily signals credible private information about herself. Omran and El-Galfy (2014) add that intentional disclosure is a crucial condition for successful competition for risk capital in the market.

Management deploys earnings management to place information on their performance before market participants (Sun \& Rath, 2008) while sustainability disclosures is employed to signal management's efforts to control the social and environmental risks within the firm (Gray, 2005)

\subsubsection{Legitimacy Theory}

The pivot of legitimacy theory is the idea that the actions or activities of an entity are in agreement with the society's system of beliefs, values, norms and definitions (Suchman, 1995). He describes three types of legitimacy: pragmatic, moral, and cognitive and pins successful activities of business organizations on the extent of the managers' ability to handle various legitimation threats and challenges.

The theory believes that there is a social contract between business and society which defines the survival and growth of the business (Shocker \& Sethi, 1973). Its observance empowers the business with the legitimate use of resources provided by the society (Dowling \& Pfeffer, 1975; Deegan, 2002). Non-adherence to the social contract upsets organizational legitimacy and spells doom for the continued existence of the business (Lindblom, 1993; Enerson \& Adegbie, 2021). To ward off the wrath of the society, management is not expected be involved in earnings management and is also under obligation to disclose the firm's footprint on the environment beyond statutory requirements.

\subsection{Empirical Review}

Many studies have concentrated on examining the likely effect of sustainability reporting as an ethical tool of communication in dissuading accrual based earnings management practices among firms. The dominant postulation is the idea that ethically compliant firms are not expected to be involved in manipulation of accounting figures. Empirical results of researches in this regard are mixed. Some studies have shown that sustainability 
reporting is negatively associated with discretionary accruals while others have established positive relationship.

Studies on sustainability reporting and earnings management have validated the idea that ethically conscious firms are less likelyto be engaging in opportunistic manipulations of earnings. Grimaldi, Caragnano, Zito and Mariani (2020) investigated the possible effect that sustainability engagement may have on earnings management. The research was on 60 companies picked from Italian Stock Exchange in 2018. The study established link between sustainability engagement and earnings management practices (discretionary accruals) was negatively related, though slightly.

$\mathrm{Ji}$, Oh, Yoon and An (2019), carried out a research work on sustainable management and discretionary accruals among companies on the standpoint of ethics in Korea. The study evaluated association between the variables with operant Jones model on 1, 418 firm year observations among listed companies in Korea from 2015 to 2017. Results revealed, among others, that sustainable management had negative association with discretionary accruals. Additionally, the study found congruence between external and internal ethics.

Velte (2019) carried out a research work on environmental, social and governance; and earnings management in Germany. The study set out to examine the former's impact on the latter using a correlation and regression analysis to evaluate 548 firm year observations among listed firms in Germany from 2011 to 2017. Results revealed, among others, that environmental, social and governance activities have negative impact on discretionary accruals with governance having highest negative influence.

Trisnawati, Wiyadi \& Setiawati (2016) evaluate sustainability reporting and earnings management. The study is centered on 37 companies that were involved in the Indonesian Sustainability Reporting Award. The findings showed economic, environmental, and social reporting had negative but significant effect on earning management (discretionary accruals).

The link between corporate governance quality and earnings management was empirically considered (Abbadi, Hijazi, \& Al-Rahahleh, 2016). Corporate governance was proxied with nomination and compensation committee, board meeting, and borad of directors. While, earnings management was represented by discretionary accruals. Secondary data was derived from Amman Stock Exchange in Jordan on all listed industrial and service firms for five year (2009 to 2013). The study showed that corporate governance had negative effective on management of earnings.

The link between CEO- duality, directors' independence and discretionary accruals was subjected to empirical review by Salihi and Kamardin (2015). The researchers sampled 24 listed firms that deal in industrial goods in Nigerian Stock Exchange. The published accounts of the sampled firms for five years (2011 to 2014) were analysed with SPSS. Discretional accruals were significantly associated with CEO - duality. The implication of the result was that CEO- duality had higher negative influence on manipulation of earnings.

Thirty five research works were subjected to meta analysis. The studies were mainly on how ownership structure and boards of directors could affect the firm's earnings management practices. The results of the analysis show that earnings management is affected by board size. Larger boards were found have had higher potentials in the prevention discretionary behaviors (Garcia-Meca \& Sanchez-Ballesta, 2009).

Specific researches on corporate social responsibility and earnings management have produced mixed empirical findings. Some studies have shown negative associations while other point to positive relationships. Hickman, Iyer and Jadiyappa (2021) studied corporate social responsibility (CSR) engagement and earnings management. The research was benchmarked on the period before and after the Company Act was enacted in 2013 in India. The Act covered provisions on improved governance and financial audits. The study segregated the sampled companies into two compartments: those who reported CSR voluntarily before enactment and those who embraced reporting thereafter. Results showed that those who reported CSR voluntarily were neck-deep in manipulation of earnings but going forward, those who involved themselves in earnings management became less comparatively.

Kolsi and Attayah (2018) inquired on whether socially responsible firms would be involved in earnings manipulation. The study selected 34 quoted firms in UAE from 2010 to 2014. The results of the inquiry indicate that there is positive relationship between discretionary accruals and the extent of social disclosures. This finding validates the postulations of the opportunistic school of thought who that believe that socially conscious entities can still tinker with the quality of their earnings.

Amar and Chakroun (2018) embarked on a study of how accruals based earnings management could be influenced by corporate social responsibility. Discretionary accruals were proxied as earnings management. The researchers picked 119 listed non-financial companies in France for five years (2010 to 2014). It was established that influence of corporate social responsibility on earnings management was not positive. The result affirms that firms that embraced corporate social responsibility were less involved in earnings management. Their empirical findings validated earlier works of Cho and Chun (2016) and Gras-Gil, Manzano, and Fernandez (2016).

Some researchers took interest in evaluating the effect of earnings management and economic value added with mixed empirical findings. Liu and Wang (2017) studied earnings management and economic value added. They selected G20 and African counties for study and extracted secondary data between 2009 and 2013 from 
COMPUSTAT; and analyzed with ordinary least squares (OLS) method. In African nations, earnings management through discretionary accruals maintained significantly positive link with economic value added. Whereas, among G20 countries, the association was in direct opposite. The mixed results could be on account of diverse national development and cultural orientations among the sampled nations.

Wang, Jiang, Liu and Wang (2015) researched intohow economic value added could be affected by earnings management in China. The paper revealed that effect of earnings management (discretionary accruals) on economic value added was significantly positive.

Similarly, Liu (2016) looked at the association which subsists between economic value added (EVA and earnings management. The study was built on data obtained from 2009 to 2013 on thenations of the North American Free Trade Agreement, Association of Southeast Asian Nations, European Union, and newly industrialized countries. The investigation produced mixed results. In North American Free Trade Agreement and European Union nations, earnings management (discretionary accruals) had a significantly inverse association with economic value added but the association was positive in Association of Southeast Asian Nations and newly industrialized countries. Real earnings management activities featured higher explanatory power among these nations.

\section{Methodology}

This segment of the paper discusses the study's methodology. Ex-post facto research design was adopted to explore how sustainability reporting can affect the discretionary accruals of earnings management of multinational companies of sub-Saharan Africa countries. This research design assumed that cause-effect relationships exist between the variables of sustainability reporting and discretionary accruals.

All the quoted multinational entities in sub-Saharan Africa countries of Zaire, Mauritius, Zimbabwe, United Republic of Tanzania, Burundi, Uganda, Kenya, Niger, Botswana, Somalia, Malawi, Ethiopia, Benin, South Africa, Angola, Togo, Cameroon, , Liberia,, Mauritania, Cote d'Ivoire, Guinea-Bissau, Sierra Leone, Zambia, Burkina Faso, Gambia, Central African Republic, Gabon, Chad, Nigeria, Guinea, Congo, Rwanda, Namibia, Ghana, Lesotho, Mozambique, Senegal, Madagascar, and Eritreaas at 31st December 2010 - 2019 constituted the study's population. Data about the variables of the research work were derived from the audited financial statement of the sampled listed multinational companies in Sub-Saharan Africa countries.

The Purposive and judgmental sampling techniques were adopted for the work. These techniques were suitable for picking the listed multinational companies in sub-Saharan Africa countries firms which passed the following three criteria. The corporations picked were listed in stock exchanges whose financial records as well as sustainability disclosures in accordance with the guidelines of Global Reporting Initiatives (GRI) were audited under enabling statutes and readily available for review for the period under review (2010-2019).

Following the aforementioned benchmarks, fifty (50) multinational firms were selected, five (5) multinational companies were selected each from ten (10) of the sub-Saharan Africa countries whose capital market was relatively developed or developing. The countries are Zimbabwe, Tanzania, Nigeria, Malawi, Kenya, Botswana, Zambia, Ghana, South Africa, and Mauritius

We adopted content analysis to analyze the contents of the annual financial reports and accounts as well as the sustainability reports of the selected multinational companies. The Global Reporting Initiative (GRI) and the various Stock Exchanges of the selected multinational companies were adopted to access the degree of compliance of the firms to sustainability reporting disclosures.

We adopted a scale with a range of 1 to 5 to measure the depth of compliance with required disclosures for sustainability reporting. The scale is calibrated as shown in the table below:

Table 3.1.1: Ranging of Scale

\begin{tabular}{|c|l|}
\hline Scale & Content Required \\
\hline 1 point & No information is provided. \\
\hline 2 points & The information is briefly disclosed. \\
\hline 3 points & The information is partially disclosed \\
\hline 4 points & The information reviewed is above average \\
\hline 5 points & The information provided is full and corroborated \\
\hline
\end{tabular}

\section{Source: Researchers' study, (2021)}

With the scaling in Table 3.1.1above, we computed the arithmetic mean of accumulated indicators for each sub-category and category to generate a final score for each sampled company. We consider this approach as appropriate since the same weight was assigned to information provided notwithstanding the total number of indicators under each aspect and category. Loh, Thomas, and Wang (2017) and Ching, GerabanToste (2017) used this approach in their earlier studies.

The study adopted the dynamic panel, using System Generalized Method of Moment (SGMM) estimation technique to account for the possibility of differences across countries and also to account for the possibility of endogeneity. In particular, the Sargan and Hansen tests were used to determine the validity of the instruments and 
the first and second order autoregressive were used to test for the possibility of auto correlated residuals.

The structural equation panel regression model is given as;:

$\mathrm{DCA}_{\mathrm{it}}=\beta_{0}+\beta_{1} \mathrm{DCA}_{\mathrm{it}-1}+\beta_{2} \mathrm{ENVR}_{\mathrm{it}}+\beta_{3} \mathrm{ECONR}_{\mathrm{it}}+\beta_{4} \mathrm{SOCR}_{\mathrm{it}}+\beta_{5} \mathrm{COGR}_{\mathrm{it}}+\varepsilon_{\text {it }}$

Where:

$\mathrm{DCA}=$ Discretionary Accruals

ENVR = Environmental Reporting

$\mathrm{ECONR}=$ Economic Reporting

SOCR $=$ Social Reporting

COGR $=$ Corporate Governance Reporting

$\varepsilon_{\text {it }}=$ Error Term

$\beta_{0}=$ intercept or the constant

$\beta_{2}-\beta_{5}=$ represent the coefficient of explanatory variables

The study expected a positive association between the measures of earnings management on sustainability reporting. The coefficients are: $\beta_{1}, \beta_{2}, \beta_{3}, \beta_{4}, \beta_{5}>0$.

\subsection{Measurement of Variables}

The variables used in the work were sustainability reporting and earnings management. The dependent variable is Discretionary Accruals (DCA) while the independent variable is sustainability reporting which is classified into Environmental Reporting (ENVR), Economic Reporting (ECONR), Social Reporting (SOCR) and Corporate Governance Reporting (COGR). These are defined in Table 1.

Table 3.2.1: Measurement of Variables

Sustainability reporting measurements (Independent variable)

\begin{tabular}{|c|c|c|c|}
\hline Measure & Abbreviation & Definition & Existing Literatures \\
\hline $\begin{array}{l}\text { Environmental } \\
\text { Sustainability } \\
\text { Reporting } \\
\end{array}$ & ENVR & $\begin{array}{l}\text { The arithmetic mean of the scores for } \\
\text { each indicator under environmental } \\
\text { category. }\end{array}$ & $\begin{array}{l}\text { Loh, Thomas, and Wang, 2017; } \\
\text { Ching, Gerab and Toste } 2017 .\end{array}$ \\
\hline $\begin{array}{l}\text { Economic } \\
\text { Sustainability } \\
\text { Reporting } \\
\end{array}$ & ECONR & $\begin{array}{l}\text { The arithmetic mean of the scores for } \\
\text { each indicator under economic } \\
\text { category. }\end{array}$ & $\begin{array}{l}\text { Loh, Thomas, and Wang, 2017; } \\
\text { Ching, Gerab and Toste } 2017 .\end{array}$ \\
\hline $\begin{array}{l}\text { Social } \\
\text { Sustainability } \\
\text { Reporting }\end{array}$ & SOCR & $\begin{array}{l}\text { The arithmetic mean of the scores for } \\
\text { each indicator under social category. }\end{array}$ & $\begin{array}{l}\text { Loh, Thomas, and Wang, 2017; } \\
\text { Ching, Gerab and Toste } 2017 .\end{array}$ \\
\hline $\begin{array}{l}\text { Governance } \\
\text { Sustainability } \\
\text { Reporting } \\
\end{array}$ & COGR & $\begin{array}{l}\text { The arithmetic mean of the scores for } \\
\text { each indicator under governance } \\
\text { category. }\end{array}$ & $\begin{array}{l}\text { Loh, Thomas, and Wang, 2017; } \\
\text { Ching, Gerab and Toste } 2017 .\end{array}$ \\
\hline \multicolumn{4}{|c|}{ Earnings Management Measurements (Dependent Variable) } \\
\hline Measure & Abbreviation & Definition & Existing Literatures \\
\hline $\begin{array}{l}\text { Discretional } \\
\text { Accruals }\end{array}$ & DCA & $\begin{array}{l}T A_{i t}=\alpha+\beta_{1}\left(\Delta \operatorname{Rev}_{i t}-\Delta R e c_{i t}\right)+ \\
\beta_{2} P P E_{i t}+\beta_{3} B M_{i t}+\beta_{4} C F O_{i t}+\varepsilon_{i t} \\
\text { Here, } \\
\text { DCA denotes the generated residual } \\
\text { TA depicts the cash obtained from } \\
\text { operations without profit. } \\
\Delta \text { Rev represents the variation in } \\
\text { revenue from previous to present } \\
\text { year. } \\
\Delta \text { Rec refers the variation in trade } \\
\text { receivables from previous to present } \\
\text { year. } \\
\text { PPE refers to the book value of } \\
\text { property, plant and equipment at year } \\
\text { end. } \\
\text { BM connotes the book-to-market } \\
\text { value of ordinary shares at year end. } \\
\text { CFO implies cash generated from } \\
\text { operations. }\end{array}$ & $\begin{array}{l}\text { Huang and Sun, 2017; Ibrahim, } \\
\text { Darus, Yusoff and Muhamad, } \\
\text { 2015; Roychowdhury (2006) }\end{array}$ \\
\hline
\end{tabular}

Source: Researchers' study, (2021) 


\section{Data Analysis and Interpretation}

This section discusses the panel data regression results used to look athow sustainability reporting can affect discretionary accruals of earnings management of multinational corporations in Sub-Saharan Africa. The section is structured as follows, Sections 4.1 and 4.2 discusses the descriptive statistics and the link between the variables (dependent and independent). Section 4.3 is devoted to panel data regressions of System General Method (SGMM) and Section 4.4 discusses the discussion of findings.

\subsection{Descriptive Statistics}

Table 4.1 below shows the features of the descriptive statistics with respect to standard deviations, minimum, maximum and mean along the observation counts for the dependent and explanatory variables.

Table 4.1: Descriptive Statistics of Sustainability Reporting and Discretionary Accruals

\begin{tabular}{llllll}
\hline Variables & Minimum & Mean & Maximum & Std. Dev. & Obs \\
\hline DCA & -6.823 & 0.396 & 2.994 & 1.417 & 500 \\
ECONR & 2.000 & 3.156 & 4.000 & 0.481 & 500 \\
ENVR & 1.000 & 3.073 & 5.000 & 1.324 & 500 \\
SOCR & 2.500 & 4.278 & 5.000 & 0.582 & 500 \\
COGR & 1.667 & 3.414 & 4.667 & 0.514 & 500
\end{tabular}

\section{Source: Researchers' computation, (2021)}

Notes: Discretionary Accruals (DCA) is the dependent variable, while the explanatory variables are Environmental Reporting (ENVR), Economic Reporting (ECONR), Social Reporting (SOCR) and Corporate Governance Reporting (COGR). All the values were calculated from the 500 firms-year observations for fifty multinational corporations in sub-Saharan Africa countries. EViews 10 was employed for the estimation.

\section{Interpretation}

From Table 4.1, DCA: The mean value and standard deviation of discretionary accruals are 0.396 and 1.417 respectively. The mean value of $39.6 \%$, suggest that on the discretionary accruals of the selected multinational firms in sub-Saharan Africa countries is comparatively low. The standard deviation value is far from the mean, suggesting that the discretionary accruals are highly vulnerable to change over time. The minimum value of -6.823 and maximum value of 2.994 show that multinational firms in sub-Saharan Africa countries have different levels of discretionary accruals.

ECONR: Economic reporting features mean value and standard deviation of 3.156 and 0.481 in that order. On the average and placed on a scale of 5, sampled multinational corporations' level of compliance with disclosure requirements of economic sustainability reporting as prescribed by GRI4 guidelines averaged 3.156. The standard deviation of $48.1 \%$ explains that the degree of variation in complying with disclosure requirements of economic sustainability reporting among the selected multinational firms in sub-Saharan Africa countries is moderately okay. The maximum value of 4 point and minimum value of 2 point indicate different levels of compliance with disclosure requirements on economic sustainability reporting among the sampled multinational entities.

ENVR: Environmental reporting features mean value and standard deviation of 3.073 and 1.324 in that order. On the average and placed on a scale of 5, sampled multinational corporations' level of compliance with disclosure requirements of environmental sustainability reporting as prescribed by GRI4 guidelines averaged 3.073. The standard deviation, which is $132.4 \%$, is considerably high. It shows the level of variation in complying with disclosure requirements of environmental sustainability reporting among the selected multinational corporations in sub-Saharan Africa. The maximum value of environmental disclosures is 5 point while the minimum value is 1 point showing different levels of compliance with disclosure requirements on sustainability reporting among the sampled multinational entities.

SOCR: Social reporting has a mean value of 4.278 while the standard deviation stands at 0.582 . The level of observed social sustainability disclosure requirements among quoted multinational companies in accordance with GRI4 guidelines represents 4.278 on a scale of 5. The standard deviation of social sustainability reporting is $58.2 \%$. This implies that among quoted multinational companies of sub-Saharan Africa countries, the extent of disparity in compliance with social sustainability reporting is quite okay. The level of social sustainability reporting varies across the selected multinational firms considering the maximum value and minimum value of 5 and 2.5 respectively.

COGR:Corporate governance sustainability reporting features mean value and standard deviation of 3.414 and 0.514 in that order. On the average and placed on a scale of 5, sampled multinational corporations' compliance level of disclosureson corporate governance sustainability as prescribed by GRI4 guidelines averaged 3.156. The standard deviation of $48.1 \%$ explains that the degree of variation in complying with disclosure requirements of economic sustainability reporting among the selected multinational firms in sub-Saharan Africa countries is moderately okay. The content of governance sustainability reporting varies across the sampled multinational firms in sub-Saharan Africa countries considering the maximum value and minimum value of 4.667 and 1.667 respectively. 
Table 4.2: Correlation Matrix of Sustainability Reporting and Discretionary Accruals

The table below highlights correlation coefficient of the variables:

\begin{tabular}{lllllll}
\hline Variables & DCA & ECONR & ENVR & SOCR & COGR & VIF \\
\hline ECONR & -0.028 & 1 & & & & 1.28 \\
ENVR & -0.140 & 0.526 & 1 & & & 2.13 \\
SOCR & -0.036 & 0.566 & 0.685 & 1 & & 2.04 \\
COGR & -0.134 & 0.692 & 0.669 & 0.779 & 1 & 2.15 \\
\hline
\end{tabular}

Source: Researchers' computation, (2021)

Notes:The table above highlights correlation coefficient of the variables. Discretionary Accruals (DCA) is the dependent variable, while Environmental Reporting (ENVR), Economic Reporting (ECONR), Social Reporting (SOCR) and Corporate Governance Reporting (COGR) are the independent variables. The variance inflation factor in the table is designed to test for multicollinearity. Five hundred (500) firms-year observations for fifty multinational corporations in sub-Saharan Africa countries were used to calculate the values. E-Views 10 was employed for the estimation.

\section{Interpretation}

To begin with, the model has no multicollinearity issue since each of the variance inflation factors for the explanatory variables is less 10 . The VIF are $2.15,2.04,2.13$ and 1.28 for corporate governance sustainability reporting, social sustainability reporting environmental sustainability reporting, and economic sustainability reporting respectively.

From the results,it is evident that social sustainability reporting, environmental sustainability reporting, corporate governance reporting, and economic sustainability reporting have negative association with discretionary accruals with correlation values of $-0.036,-0.140,-0.134$, and -0.028 respectively. The implication is that increases in economic sustainability reporting, environmental sustainability reporting, social sustainability reporting, corporate governance reporting, and size of the company will result to decrease in discretionary accruals.

\subsection{Test of Hypotheses}

Research Objective: evaluate the effect of sustainability reporting on discretionary accruals of multinational corporations in Sub-Saharan Africa

Research Question: How does sustainability reporting affect discretionary accruals of multinational corporations in Sub-Saharan Africa?

Research Hypothesis: Sustainability reporting does not have significant effect on discretionary accruals of multinational corporations in Sub-Saharan Africa

Table 4.3.1Sustainability Reporting and Discretionary Accruals of Multinational Corporations in SubSaharan Africa

Dependent Variable: DCA

\begin{tabular}{lllll}
\hline Variables & Coeff & S.E & Z-test & Prob. \\
\hline L.DCA & $1.0444^{* * *}$ & 0.029 & 36.553 & 0.000 \\
ECONR & 0.0003 & 0.006 & 0.041 & 0.967 \\
ENVR & -1.5675 & 0.955 & -1.641 & 0.101 \\
SOCR & $-0.7795^{* * *}$ & 0.251 & -3.110 & 0.002 \\
COGR & 0.8805 & 0.492 & 1.790 & 0.073 \\
Constant & -0.3590 & 0.306 & -1.172 & 0.241 \\
\hline Observations & 450 & & & \\
Adjusted R & 0.43 & & & \\
Number of group & 50 & & & \\
Wald chi-square & $668.67(0.000)$ & & & \\
AR1 test & $-7.10(0.000)$ & & & \\
AR2 test & $-1.17(0.242)$ & & & \\
Hansen test & $0.57(0.902)$ & & & \\
Sargan test & $1.25(0.408)$ & & & \\
\hline
\end{tabular}

Source: Researchers' computation, (2021)

Notes: Table 4 reports System General Method of Moment (SGMM) regression results of the effects of sustainability reporting on discretionary accruals of multinational corporations in Sub-Saharan Africa. The dependent variable is Discretionary Accruals (DCA). The regressors are Environmental Reporting (ENVR), Economic Reporting (ECONR), Social Reporting (SOCR) and Corporate Governance Reporting (COGR). ${ }^{* * *}$ Significant at $1 \%,{ }^{* *}$ Significant at $5 \%,{ }^{*}$ Significant at $10 \%$.

$\mathrm{DCA}_{\mathrm{it}}=\beta_{0}+\beta_{1} \mathrm{DCA}_{\mathrm{it}-1}+\beta_{2} \mathrm{ENVR}_{\mathrm{it}}+\beta_{3} \mathrm{ECONR}_{\mathrm{it}}+\beta_{4} \mathrm{SOCR}_{\mathrm{it}}+\beta_{5} \mathrm{COGR}_{\mathrm{it}}+\varepsilon_{\mathrm{it}}$

$\mathrm{DCA}_{\mathrm{it}}=-0.359+1.044 \mathrm{DCA}_{\mathrm{it}-1}-1.568 \mathrm{ENVR}_{\mathrm{it}}+0.0003 \mathrm{ECONR}_{\mathrm{it}}-0.779 \mathrm{SOCR}_{\mathrm{it}}+0.881 \mathrm{COGR}_{\mathrm{it}}$ 


\section{Interpretation}

The System General Method of Moment was employed to ensure that post estimation tests parameters are appropriatefor the investigation of the effect of sustainability reporting on discretionary accruals of multinational corporations in Sub-Saharan Africa. Ideally, four types of test are generally considered and they are as follows; first, the serial correlation of autoregressive order 1, with the null hypothesis that there is no serial correlation Second, the serial correlation of autoregressive order 2, with the null of serial correlation. Third, the Hansen test of over-identifying restrictions with the null that the model specified has valid instrumentation. Lastly, the Sargan test that the specified variables are proper instruments, with the null that the model specified are proper instruments.

The serial correlation of autoregressive of order 1 with a statistic value of -7.10 is significant at 1 per cent. We accepted the alternate that there is serial correlation. This is in line with the SGMM that the AR1 should be significant and correlated. The AR2 with a statistic of -1.17 is not significant, and the alternative of no serial correlation was accepted. This is in conformity with the literature that the AR2 should be serial independence.

The Hansen test statistic of 0.57 is statistically insignificant, thus, the null that the model has valid instrumentation was not rejected, and therefore, the variables are valid instrumentation of the estimated model. The Sargan test is 1.25 with a value of probability of 40.8 per cent indicates the variables are proper instruments of the estimated model. From the post- estimation tests result reported above it shows that estimated model is efficiency and thus, inferences can be drawn from the result.

From the results in Table 4.3.1., it is noticeable that the lag of discretionary accruals, economic sustainability reporting and corporate governance sustainability reporting has positive relationship with discretionary accruals, while social sustainability reporting and environmental sustainability reporting are negatively related to discretionary accruals. In addition, there is it is evident that the lag of discretionary accruals and social sustainability reporting has significant association with discretionary accruals of selected multinational firms in sub-Saharan Africa countries (L.DCA $=1.044, \mathrm{Z}$-test $=36.553, \mathrm{p}<0.05$ and SOCR $=-0.779, \mathrm{Z}$-test $=-3.110, \mathrm{p}<$ $0.05)$, respectively. This implies that the lag of discretionary accruals and social sustainability reporting were significant factors influencing changes in discretionary accruals of selected multinational firms in sub-Saharan Africa countries.

Conversely, there is evidence that the environmental sustainability reporting, economic sustainability reporting, and corporate governance sustainability reporting do not have significant relationship with the discretionary accruals of selected multinational firms in sub-Saharan Africa countries $(\mathrm{ECONR}=0.0003$, Z-test $=$ $0.041, \mathrm{p}>0.05, \mathrm{ENVR}=-1.568, \mathrm{Z}$-test $=-1.641, \mathrm{p}>0.05$ and COGR $=0.881, \mathrm{Z}$-test $=1.790, \mathrm{p}>0.05)$ respectively. The implication of this is that economic sustainability reporting, environmental sustainability reporting and corporate governance sustainability reporting were not significant factors influencing changes in discretionary accruals of selected multinational firms in sub-Saharan Africa countries.

Concerning the magnitudes of the estimated parameters 1 unit increase in lag of discretionary accruals, economic sustainability reporting and corporate governance sustainability reporting will lead to $1.044,0.0003$ and 0.881 increase in discretionary accruals respectively, while 1 unit increase in environmental sustainability reporting and social sustainability reporting will lead to a fall of 1.568 and 0.779 in discretionary accruals respectively.

The Adjusted $\mathrm{R}^{2}$ which measures the proportion of the changes in the discretionary accruals of multinational corporations in Sub-Saharan Africa countries due to changes in previous value of discretionary accruals, environmental reporting, economic reporting, social reporting, and corporate governance reporting is $43 \%$. This means that the independent variables in the model can explain $43 \%$ of the variance in discretionary accruals of multinational corporations in Sub-Saharan Africa countries leaving 57\% to other factors which were not included in the model.

The Wald Chi Square Statistic which stands at 668.67 as well as a probability value of 0.000 is significant at $1 \%$ level.The implication is that the null that sustainability reporting has no significant effect on discretionary accruals of multinational corporations in Sub-Saharan Africa. On account of this, we rejected the null hypothesis and accepted the alternate hypothesis that sustainability reporting has significant effect on discretionary accruals of the entities under review.

\subsection{Discussion of Findings}

The main goal of the paper is to account for how sustainability reporting affects discretionary accruals of multinational corporations in Sub-Saharan Africa for the period of 2010-2019. The result of the study reveals that the lag of discretionary accruals, corporate governance sustainability reporting and economic sustainability reporting has positive relationship with discretionary accruals, while social sustainability reporting and environmental sustainability reporting are negatively linked to discretionary accruals. In addition, the result of the Wald Chi Square suggests that the null hypothesis be rejected. Consequently, we accepted the alternate hypothesis which states that sustainability reporting has significant effect on discretionary accruals of multinational corporations in Sub-Saharan Africa. The outcome of this study is in tandem with earlier findings of the following 
earlier works: Grimaldi, Caragnano, Zito and Mariani (2020), Ji, Oh, Yoon and An (2019), Velte (2019), Amar and Chakroun (2018), and Trisnawati, Wiyadi \& Setiawati (2016). However, the research results of

Hickman, Iyer and Jadiyappa (2021) and Kolsi and Attayah (2018) do not agree with our findings. They both concluded that that corporate social responsibility involvement by firms has positive association with earnings management. Their findings align to the assumption that sustainability reporting or corporate social responsibility reporting is a smokescreen to conceal unethical practices of managers.

\section{Conclusion and Recommendation}

The focus of the study was to assess how discretionary accruals of earning management could be influenced by sustainability reporting among fifty (50) multinational corporations in Sub-Saharan Africa for the period 20102019. The preliminary results from the correlation test revealed that corporate governance sustainability reporting, economic sustainability reporting, social sustainability reporting, and environmental sustainability reporting have negative association with discretionary accruals. The variance inflation factor revealed that all the explanatory variables of corporate governance sustainability reporting, economic sustainability reporting, social sustainability reporting, and environmental sustainability reporting were not related, providing evidence of non-collinearity.

The result of the study reveals that the lag of discretionary accruals, corporate governance sustainability reporting and economic sustainability reporting has positive relationship with discretionary accruals, while social sustainability reporting and environmental sustainability reporting are negatively associated to discretionary accruals. In addition and based the model's Wald Chi Square, wereject the null hypothesis which presupposes that sustainability reporting has no significant effect on discretionary accruals of multinational corporations in SubSaharan Africa and thereby accept the alternate hypothesis. We, therefore, conclude that sustainability reporting has significant effect on discretionary accruals of multinational corporations in Sub-Saharan Africa. The study recommends that management should ensure strict compliance with sustainability reporting especially on corporate governance sustainability reporting and economic sustainability reporting which have positive association with discretionary accruals to curtail earnings management.

This work contributes to the existing body of literature by bringing up new evidence about the relationship between sustainability reporting and discretionary accruals among multinational corporations in Sub Saharan Africa.

This study examined the association between sustainability reporting and discretionary accruals in subSaharan Africa. Future studies should focus attention on other continents.

\section{References}

Abbadi, S. S., Hijazi, Q. F., \& Al-Rahahleh, A. S. (2016). Corporate governance quality and earnings management: Evidence from Jordan. Australasian Accounting, Business and Finance Journal, 10(2), 54-75.

Acar, G., \& Yilmaz, I. (2020). The impact of discretionary accruals on corporate investment decisions: Evidence from GCC countries. Academic Journal of Interdisciplinary Studies, 9 (6), 193-205.

Aerts, W., Cheng, P., \&Tarca, A., (2013).Management's earnings justification and earnings management under different institutional regimes.Corporate Governance: An International review, 21(1), 93-115.

Ahmed, A. S., Takeda, C., \& Thomas S., (1999).Banking loan loss provisions: A reexamination of capital management, earnings management and signaling effects.Journal of Accounting and Economics, 28(1), 1-25.

Akintoye, I. R., Taiwo, O. J., \& Owolabi, B. A. (2020). Sustainability accounting and competitive advantage of quoted companies in Nigeria. International Journal of Accounting and Financial Reporting, 10 (2), 119-134.

Altamuro, J., Beatty, A., \& Weber, J., (2005). Motives for early revenue recognition: Evidence from SEC staff accounting bulletin (SAB 101). The Accounting Review, 80(2), 373-402.

Amar, A. B., \& Chakroun, S. (2018). Do dimensions of corporate social responsibility affect earnings management? Evidence from France. Journal of Financial Reporting and Accounting, 16(2), 348-370.

Becchetti, L., Di Giacomo, S., \& Pinnacchio, D. (2008). Corporate social responsibility and corporate performance: Evidence from a panel of US listed companies. Applied Economics, 40, 541-567.

Chalayer-Rouchon, S., Degeorge, F., \& Le Nadant, A. L. (2001).Objectifs de la gestion des résultatsetmarchés financiers. Faire de la rechercheencomptabilitéfinancière, 235-249.

Cho, E., \& Chun, S. (2016). Corporate social responsibility, real activities earnings management, and corporate governance: Evidence from Korea. Asia-Pacific Journal of Accounting \& Economics, 23 (4), 400-431.

Cohen, D. A., \& Zarowin, P. (2010). Accrual-based and real earnings management activities around seasoned equity offerings. Journal of accounting and Economics, 50(1), 2-19.

De Villiers, C., \& Marques, A. (2016).Corporate social responsibility, country-level predispositions, and the consequences of choosing a level of disclosure. Accounting and Business Research, 46(2), 167-195.

Deegan, C. (2000). Financial AccountingTheory.Beijing: Mc Graw Hill.

Deegan, C. (2002). The legitimising effect of social and environmental disclosures-a theoretical foundation. Accounting, Auditing and Accountability Journal, 15(3), 282-311. 
Dowling, J., \& Pfeffer, J. (1975). Organizational legitimacy: Social values and organizational behavior. Pacific sociological review, 18(1), 122-136.

García - Meca, E., \& Sánchez - Ballesta, J. P. (2009). Corporate governance and earnings management: A meta analysis. Corporate governance: an international review, 17(5), 594-610.

Global Reporting Initiative (2013).G4 Sustainability Guidelines, retrieved on 23 ${ }^{\text {rd }}$ March,2020 fromhttps:/www2.globalreporting.org/standards/g4/Pages/default.aspx.

Gras-Gil, E., Manzano, M. P., \& Fernández, J. H. (2016).Investigating the relationship between corporate social responsibility and earnings management: Evidence from Spain.BRQ Business Research Quarterly, 19 (4), 289-299.

Gray, R., Kouhy, R. \& Lavers, S. (1995). Corporate social \& environmental reporting; A review of the literature and a longitudinal study of U.K. Disclosure. Accounting, Auditing \& Accountability Journal, 8 (2), 47-77.

GRI (2011).Sustainability reporting guidelines, version 3.1.

Gulzar, M. A. \& Wang, Z. (2011). Corporate governance characteristics and earnings management: Empirical evidence from Chinese listed firms. International Journal of Accounting and Financial Reporting, 1(1), 133151.

Guthrie, J., \& Parker, L. D. (1989). Corporate social reporting: A rebuttal of legitimacy theory. Accounting and Business Research, 19(76), 343-52.

Hahn, R., \& Kühnen, M. (2013). Determinants of sustainability reporting: a review of results, trends, theory, and opportunities in an expanding field of research. Journal of cleaner production,59, 521.https://doi.org/10.1016/j.jclepro.2013.07.005

Hooghiemstra, R. (2000). Corporate communication and impression management-new perspectives why companies engage in corporate social reporting. Journal of business ethics, 27(1-2), 55-68.

Hu, M., \& Loh, L. (2018). Board governance and sustainability disclosure: A cross-sectional study of Singaporelisted companies. Sustainability, 10(7), 1-14.

Huang, X. S., \& Sun, L. (2017).Managerial ability and real earnings management. Advances in accounting, 39 , 91-104.https://doi.org/10.1016/j.adiac.2017.08.003

Ibrahim, M. S., Darus, F., Yusoff, H., \& Muhamad, R. (2015). Analysis of earnings management practices and sustainability reporting for corporations that offer Islamic products and services. Procedia Economics and Finance, 28, 176-182.

Ji, S. H. (2018). The effect of the investor relation on real earnings management-according to firm's governance and audit quality. Tax Accounting Research, 55(1), 29-52.

Ji, S. H., \& An, S. B. (2019). A study on the real earnings management of shared growth corporate. Journal of International Trade Commerce, 15(2), 389-406.

Ji, S. H., Oh, H. M., Yoon, K. C., \&An, S. B. (2019). A study on earnings management in companies achieving sustainability: Accruals-based and real earnings management. The Journal of Distribution Science, 17(9), 103-115.

Kolsi, M. C., \& Attayah, O. F. (2018). Are socially responsible firms less engaged in earnings management? Evidence from ADX listed companies. International Journal Business Innovation and Research, 17 (4), 536560.

Lin, J. W., \& Hwang, M. I. (2010). Audit quality, corporate governance, and earnings management: A meta analysis. International journal of auditing, 14(1), 57-77.

Lindblom, C. K. (1993). The implication of organization legitimacy for corporate social performance and disclosure. Paper presented at the Critical Perspectives in Accounting Conference, New York.

Lizińska, J., \& Czapiewski, L. (2018). Towards economic corporate sustainability in reporting: What does earnings management around equity offerings mean for long-term performance?. Sustainability, 10(12), 1-23.

Loh, L., Thomas, T., \& Wang, Y. (2017). Sustainability reporting and firm value: Evidence from Singapore-listed companies. Sustainability, 9(11), 2112.

Magness, V. (2006). Strategic posture, financial performance and environmental disclosure: An empirical test of legitimacy theory. Accounting, Auditing \& Accountability Journal, 19(4), 540-563.

Mobus, L. J. (2005). Mandatory environmental disclosures in a legitimacy theory context. Accounting, Auditing \& Accountability Journal, 18(4), 492-517.

Myers, S. C., \& Majluf, N. S., (1984). Corporate financing and investment decisions when firms have information that investors do not have. Journal of Financial Economics, 13(1), 187-221.

Orlitzky, M., \& Swanson, D. L. (2012). Assessing stakeholder satisfaction: Toward a supplemental measure of corporate social performance as reputation. Corporate Reputation Review, 15, 119-137.

Owen, D. (2008). Chronicles of wasted time? A personal reflection on the current state of, and future prospects for social and environmental accounting research.Accounting, Auditing and Accountability Journal, 21 (2), 240-267.

Patten, D. M. (1992). Intra-industry environmental disclosures in response to the Alaskan oil spill: a note on 
legitimacy theory. Accounting, Organizations and Society, 17(5), 471-475.

Ross, S. A. (1977). The determination of financial structure: the incentive-signalling approach. The bell journal of economics, 8(1), 23-40.

Roychowdhury, S. (2006).Earnings management through real activities manipulation. Journal of accounting and economics, 42(3), 335-370.

Salihi, A. A., \& Kamardin, H. (2015).The relationship between CEO dualities, directors' independence and discretionary accruals in the Nigerian industrial goods companies.European Journal of Accounting, Auditing and Finance Research, 3 (12), 1-16.

Schaltegger, S., Etxeberria, I. Á.,\& Ortas, E. (2017). Innovating corporate accounting and reporting for sustainability-attributes and challenges. Sustainable Development, 25(2), 113-122.

Schipper, K. (1989). Earnings management. Accounting horizons, 3(4), 91-102.

Siregar, S. V., \& Utama, S. (2008). Type of earnings management and the effect of ownership structure, firm size, and corporate-governance practices: Evidence from Indonesia. The international journal of accounting, 43(1), $1-27$

Spence, M., (1973).Job market signaling.Quarterly Journal of Economics, 87(3), 355-374.

Sun, Y., Wang, W., Wang, X., \& Zhang, W. (2013). Shareholder activism and earnings management incentives: An empirical examination of shareholder proposals in the United States. Journal of International Financial Management \& Accounting, 24(3), 234-260.

Velte, P. (2019). The bidirectional relationship between ESG performance and earnings management-empirical evidence from Germany. Journal of Global Responsibility, 10(4), 322-338.

Waddock, S. A., \& Graves, S. B. (1997).The corporate social performance-financial performance link. Strategic management journal, 18(4), 303-319.

Yun, W. Y., Ryu, Y. R., \& Ji, S. H. (2019). The ceo power and earnings management-accounting and real earnings management. Journal Business Research, 34(2), 157-184.

Appendix: List of Selected Multinational Companies by Country

\begin{tabular}{|l|l|l|}
\hline 1 & Botswana & $\begin{array}{l}\text { Sefalana Holding, A-Cap Resources Limited, Funmart Botswana, Botswana } \\
\text { Telecommunications, Chobe Holding }\end{array}$ \\
\hline 2 & Ghana & Fanmilk Ghana, Guinness Ghana, Benson Oil Palm Ghana, Total Ghana, Unilever Ghana \\
\hline 3 & Kenya & $\begin{array}{l}\text { Boc Kenya Plc, British American Tobacco Kenya Plc, East African Breweries, East African } \\
\text { Portland Cement, Every Day E. A. Plc }\end{array}$ \\
\hline 4 & Malawi & $\begin{array}{l}\text { Ilovo Sugar, Blantyre Hotels Plc, Telekom Network, Sunbird Hotels and Resorts, Press } \\
\text { Corporation }\end{array}$ \\
\hline 5 & Mauritius & $\begin{array}{l}\text { Lez Gas Industries, Livestock Feed Mauritius, Livestock Feed Mauritius, Ciel Textile, Dale } \\
\text { Capital Group, ENL Land }\end{array}$ \\
\hline 6 & Nigeria & $\begin{array}{l}\text { Cadbury Nigeria Plc, Lafarge Wapco Plc, Nestle Nigeria Plc, PZ Cussons Nigeria Plc, } \\
\text { Unilever Nigeria Plc }\end{array}$ \\
\hline 7 & $\begin{array}{l}\text { South } \\
\text { Africa }\end{array}$ & $\begin{array}{l}\text { Accentuate, Panafrican Resources Integrated, African Rainbow Minerals, Aspen } \\
\text { Pharmacare Holdings, Distell Group }\end{array}$ \\
\hline 9 & Zanzania & $\begin{array}{l}\text { Barrick Gold Corporation, Tatepa Plc, Tanzania Cigarette Plc, Tanga Cement, Tanzania } \\
\text { Portland }\end{array}$ \\
\hline 10 & Zimbabwe & $\begin{array}{l}\text { British American Tobacco Zambia Plc, Lafarge Zambia Plc, National Breweries Plc, First } \\
\text { Quantum Minerals, Zambian Breweries Plc } \\
\text { Bistish American Tobacco Zimbabwe, Lafarge Zimbabwe, Innscor Africa, PPC, African }\end{array}$ \\
\hline
\end{tabular}

Source: Researchers' Compilation, (2021) 